\title{
AL-KINDĪ, A NINTH-GENTURY PHYSICIAN, PHILOSOPHER, AND SCHOLAR
}

by

\section{SAMI HAMARNEH}

FROM 9-12 December, 1962, the Ministry of Guidance in Iraq celebrated the thousandth anniversary of one of the greatest intellectual figures of ninth century Baghdād, Abū Yūsuf Ya'qūb ibn Ishāq al-Kindī (Latin Alkindus). ${ }^{1}$ However, in the aftermath of this commendable effort, no adequate coverage of al-Kindi as a physician-philosopher of ardent scholarship has, to my knowledge, been undertaken. This paper, therefore, is intended to shed light on his intellectual contributions within the framework of the environment and time in which he lived. My proposals and conclusions are mainly based upon a study of al-Kindi's extant scientific and philosophical writings, and on scattered information in the literature of the period.

These historical records reveal that al-Kindi was the only man in medieval Islam to be called 'the philosopher of the Arabs'. ${ }^{2}$ This honorary title was apparently conferred upon him as early as the tenth century if not during his lifetime in the ninth. He lived in the Abbasids' capital during a time of high achievement. As one of the rare intellectual geniuses of the century, he contributed substantially to this great literary, philosophic, and scientific activity, which included all the then known branches of human knowledge.

Very little is known for certain about the personal life of al-Kindi. Several references in the literary legacy of Islam, however, have assisted in the attempt to speculate intelligently about the man. Most historians of the period confirm the fact that al-Kindi was of pure Arab stock and a rightful descendant of Kindah (or Kindat al-Mulūk), originally a royal south-Arabian tribe ${ }^{3}$. The last of their kings was al-Ash'ath ibn Qays ibn Ma'di Karib (b. ca. 597) who in $6_{3} \mathrm{I}$ was the first among Kindah to embrace Islam and become a personal friend of Muhammad. Thereafter, he accompanied the victorious Arab armies to Syria, Iraq, and Iran (Persia). Then Caliph 'Uthmān $\left(6_{44}-656\right)$ sent him on a special mission to Adharbayjān. Later he built a house in the capital city of

\footnotetext{
1 Actually, the extensive celebration of December 1962 took place to commemorate the founding of the city of Baghdād by Caliph al-Mansūr in 762-766 and to honor the memory of al-Kindi who studied and later established his fame in the Abbasids' capital over 1, 100 years ago. See 'Umar Farrükh, Safahät min Hayāt al-Kind̄̇ Wa-Falsafatih, Beirut, Dār al'Ilm lil-Malayīn, Dec., 1962; and 'al-Kindì Wa-Turāthuh al-Kāmil', al-'Ulum, Beirut, 1963, 8, no. 1, 33-42. See also Kūrkìs 'Awwād, Ya'qub Ibn Ishäq al-Kindī, Hayätuh wa-Atharuh, Baghdād, Tamaddun Press, 1962; and Sami Hamarneh, 'The life and ideas of al-Kindi', Middle East Forum, Beirut, 1963, 39, no. 6, 35-38.

3 Abū al-Qāsim Șā'id ibn Ahmad ibn Șā'id al-Andalusî, Țabaqăt al-Umam, Cairo, Mațar Press, n.d., p. 59; and Muhammad ibn Isḥāq ibn al-Nadim, Al-Fihrist, Ćairo, Istiqāmah Press, 1929, p. 371 .

3 Ibid.; Jamäll al-Dìn 'Alì ibn Yūsuf al-Qifți, Ikhbar al-'Ulamä bi-Akhbär al-Hukamā, Cairo, Sa'ādah Press, 1326 A. H. [1908], p. 240; and Abū al-Faraj Gregorius Bar Hebraeus, Tä̀rikh Mukhtaṣar al-Duwal, edited by Anțūn Salihạnī, Beirut, Catholic Press, 1890, p. 259.
} 


\section{Al-Kindi, a Ninth-Century Physician, Philosopher and Scholar}

'Ali, al-Kūfah, Iraq, where he resided until his death about 66r.4 His son, Muhammad, grandson 'Abd al-Rahmān, and their children were opposed to the Umayyad caliphate $\left(66 \mathrm{I}-75^{\circ}\right)$ and perhaps helped those who strove towards its fall. They rose again to power with the triumph of the Abbasids. Al-Kindī's father, Ishāq, was appointed governor of al-Küfah during the reigns of Caliph al-Mahdi (775-785) and his son al-Rashid (786-809). In the very early years of the ninth century, al-Kindi was born. His father died before 809 leaving al-Kindi a young orphan but with wealth and great prestige. ${ }^{5}$ From al-Kūfah, young al-Kindi went to the city of al-Bașrah where he inherited a large estate bought by his forefather, al-Ash'ath. Here, he also studied Arabic language and literature. He moved, thereafter, to Baghdād during the reign of al-Ma'mūm (813-833), to continue his learning and, later, his philosophic and scientific productivity in this celebrated capital of the Abbasids, ${ }^{6}$ which was then one of the greatest cultural centres in the civilized world. In this city, al-Kindi was not enticed by the glamour and social prestige of a political career but interested rather in the world of the intellect. Backed by adequate financial support, he pursued his studies and devoted his time and talents to philosophy and the sciences. Aided by his acquaintance with the Greek language and possibly with Syriac, he was able to go to the original sources. His learning soon brought him the favour of office in the ruler's palace. ${ }^{7}$ Caliph al-Mu'tașim (reigned 833-46), who greatly admired al-Kindi's scholarship and broad learning, promoted him to the position of a court astronomer. Furthermore, he was charged with the honourable task of tutoring the Caliph's son, Ahmad, at his new residence in Sāmarrā (Surrā Man Ra'ā). ${ }^{8}$ To al-Mu'tașim, he dedicated $F \bar{\imath}$ al-Falsafah al-Ūla , probably the largest of his works on philosophy, of which only Part One is known to exist. It would seem that he was, nevertheless, more attached to the son to whom he dedicated several epistles. Most of these short treatises are extant in the original language, as for instance, his Book on the Elucidation [getting out, istikhrajj] of the Concealed, which has not yet been studied. He often introduced these epistles by addressing this prince Ahmad as 'the son of the great nobility, and the wise, efficient rulers'.

Unfortunately, this friendly relationship with the Abbasid palace was cut short by the rise to power of reactionary forces during the reign of al-Mutawakkil $(847-61)$ and for a long time thereafter. Hiding under the guise of orthodox religion, these countermovements aimed at subduing free thinking and original

4 Ahmad ibn 'Alī al-Khațīb al-Hāfiz al-Baghdādi (1002-1071), Tärìkh Baghdād, vol. I, Cairo, Sa'ādăh Press, 1931, pp. 196-197; and Aḥmad ibn 'Alì ibn Hajar al-'Asqalānī, Al-Ișäbah fí Tamyiz al-Șahäbah, Cairo, 1939, vol. 1, p. 66.

¿ Muștafā 'Abd al-Razzāq, Faylasüf al-'Arab wäl-Mu'allim al-Thānī, Cairo, Ihyā al-Kutub al'Arabiyyah, 1945, pp. 10-19. See also Ferdinand Wüstenfeld, Geschichte der arabischen Aerzte und Naturforscher, Göttingen, 1840, p. 22.

6 See the report by the tenth century physician-biographer, Sulaymān ibn Hassān ibn Juljul, Tabaqăt $a l-A t i b b \bar{a}$ wäl-Hukamā, edited by Fuād Sayyid, Cairo, Instit. franç. Arch. Orient, 1955, pp. 73-74.

7 Ibid.; and Heinrich Suter, Die Mathematiker und Astronomen der Araber und ihre Werke, Leipzig, Teubner, 1900, pp. 23-26.

${ }^{8}$ Carl Brockelmann, Geschichte der arabischen Litteratur, Leiden, Brill, I943, vol 1, pp. 230-231. Jamāl al-Din Muhammad ibn Nubātah al-Mișri (d. 1367) in his Sarh al-'Uyün fi Sharh Risälat ibn Zaydün, 4th ed., Cairo, Mawsū'āt Press, 1321 A. H. [1903], pp. 157-1 58, confirms that 'more glamour and beauty was added to the reign of al-Mu'tasim because of him (al-Kindi) and his fertile cultural productivity'. See Taqi Radi, Sirat Ya qub ... al-Kindī, Baghdād, 1962, pp. 35-61. 


\section{Sami Hamarneh}

cultural contributions based on observation of natural phenomena and the utilization of the philosophy and sciences of the classical period. The Caliph himself supported them against Muslim sects which did not subscribe to orthodox beliefs and dogmas. Adherents to the Mu'tazilite school of thought, for example, were persecuted because of their doctrines regarding free will and the authority of the mind, and their claim that the Qur'ān is created (makhlüq). Al-Kindi was not a true follower of this sect, ${ }^{9}$ but some of his ideas on monotheism and justice agreed with their teaching. His admiration for and propagation of Greek philosophy, together with his good relations with former caliphs who had defended the Mu'tazilites, also made him suspect. Therefore, when the sons of Mūsā ibn Shākir brought heavy and unwarranted charges against al-Kindi, al-Mutawakkil ordered the confiscation of his library. ${ }^{10}$ The historian, al-Tabari (d. 923) tells that in 862, under the instigation of the same sons of Muhammad ibn Mūsā, Ahmad ibn al-Mu'taṣim was denied his right to the throne because of his friendship with al-Kindi and his support of his philosophical activities. ${ }^{11}$

Unfortunately, pretenders to orthodoxy and religious fanatics whom alKindi called 'unworthy seekers of high political positions who clamour for their own selfish ambitions, and as hypocrites strive only for material gains', ${ }^{12}$ often outrivalled free thinkers. It was not strange then to find that many of them antagonized al-Kindi and attacked his intellectual pursuits bitterly, a fact that possibly had some bearing on his medical and philosophical activities. Among them was Abū Ma'shar Ja'far ibn al-Balkhī (Latin Albumasar, d. 885), a student of Islamic traditions (hadith) until he was forty-seven years of age, who instigated the vulgar crowd against al-Kindi. The latter, however, was of a nobler character and, in a very intelligent manner, was able to change the relationship from animosity to one of friendliness. He sent, we are told, a mutual friend to $\mathrm{Abu \overline {u }} \mathrm{Ma}^{\text {'shar }}$ to persuade him to study mathematics and astronomy. In reading his source material, $\mathrm{Abu} \mathbf{M a}$ 'shar needed to refer repeatedly to al-Kindi's writings in these fields, and from then on he refrained from bothering him any further. ${ }^{13}$ In the same generous spirit, al-Kindi performed his duties and expert services as a physician to foes as well as friends. ${ }^{14}$

Except for urgent contacts with patrons and scholars in the Abbasid capital,

- It is unlikely that al-Kindi was a follower of the Mu'tazilite doctrines. Indeed, he was attacked bitterly by the pioneer Mu'tazilite 'Amrū ibn Bahr al-Jāhi. (d. 869) in his al-Bukhalä, edited and annotated by Tăhā al-Hajajiri ,Cairo, Dār al-Ma'ärif, 1958 , pp. 81-93, if the Kindi mentioned here is indeed this 'philosopher of the Arabs'. The criticisms were not centered on al-Kindï's intellectual achievement but rather on matters related to hospitality and social affairs. In my judgment, the style, choice of words, and subject matter of the quotations cited by al-Jāhiz differ widely from the other known genuine letters of $\mathrm{Ya}^{\prime}$ qūb ibn Ishāq al-Kindi.

10 Muwaffaq al-Din Ahmad ibn al-Q̄āsim ibn Abi Uşaybi'ah, 'Uyĩn al-Anbā fí tabaqăt al-Ațibbā, Beirut edition, Där al-Fikr, 1957, vol. 2, pp. 180-181.

11 Muhammad ibn Jarir al-Ṭabari, Tärikh al-Umam (al-Rusul) wäl-Mulük, Cairo, Istiqāmah Press, 1939, vol. 7, p. 417 .

19 Kindī, Fĭ al-Falsafah al-Ūlä, edited by Muhammad A. Abū Ridah, Rasäil al-Kindī al-Falsafiyah, Cairo, I'timād Press, 1950, vol. 1, p. 104. According to Ibn Nubātah, Sarh, p. 158, this is one of the three best works written by al-Kindi.

${ }^{13}$ Nadim, Fihrist, p. 400; Ușaybi'ah, 'Uyīn, vol. 2, p. 180; and Lucien Leclerc, Histoire de la médecine arabe, Paris, 1876, vol. 1, p. 161 .

14 Qifți, Ikhbär, pp. $246-247$. 


\section{Al-Kindi, a Ninth-Century Physician, Philosopher and Scholar}

al-Kindi lived in the seclusion of his home which contained his rich library. His contemporary, al-Jāhiz, repeatedly and harshly criticized al-Kindi, with very little justification, for being mean and avaricious. ${ }^{15}$ Other opponents went so far as to spread rumours to injure his good reputation as a devout Muslim by accusing him of being a Jew or a Christian and teaching his son Muhammad to be miserly. ${ }^{16}$ Al-Kindi's writings leave no doubt that he was not only a Muslim but also a zealous defender of this faith. He confirmed his belief in ${ }^{16}$ the sayings of Muhammad, the faithful (al-sädiq) . . . and the message he declared as from God Almighty agreed with all true rational measures (almaqāyīs al-aqliyyah).' And in his admiration of the Qur'ān, he exclaimed, 'Tell me, if in human philosophy any man could gather in so few verses and in the same number of words what God spoke in these quoted passages.'17 There are numerous references in al-Kindi's writings to the omnipotence of God. Amazed by the orderliness and majesty of God's handiwork, he remarked, 'How perfect is all made by God . . . who made the universe from nothing (ays min lays).' He also saw 'a very clear evidence in the phenomena observed by our senses that all were designed . . . by God, the First Designer.' He then applauded 'the wonderful harmony which exists in the Universe so that the effect, response, and submission of one part of it to the other show the perfect precision in which it is constructed (itqän hay'atih). All this gives an undeniable proof that it was created . . . by the most perfect and wisest Designer.'18

In 86 $\mathrm{r}$, al-Kindi regained his library and possibly some of his prestige, but not his status with the court because of his friendship with prince Ahmad. Yet he continued his loyalty to the state. In 870 , in his epistle $F_{\bar{\imath}}$ Kammiyat Mulk al-'Arab (on the duration of the Arabic Empire), he foretold from the conjunction of the stars (especially Scorpio with Venus) that the Abbasid dynasty would survive until about the year $1300 .{ }^{19}$ This 'prediction' was made at a time when Baghdād was threatened by the revolt of the Qarmatians, an extremely radical branch of the Ismā'ilites, which shook the caliphate to its very foundation. ${ }^{20}$ At this time, al-Kindi was suffering greatly from pains in the knees and lower limbs which later progressed to the head. It is reported that he abandoned drinking wine for a honey mixture, but to no avail. He died not later than 873 , from what could possibly be diagnosed in modern terminology as obliterative

\footnotetext{
15 It is very possible that the criticism by al-Jāhiz, Bukhalä, pp. $81-93$, formed the basis for the report by al-Nadim, Fihrist, p. 371 and other biographers later on.

16 Ușaybi'ah, Uyūn, vol. 2, p. 182; and Shams al-Din Mahmūid al-Shahrazūrī, Nuzhat al-Arwāh wa-Rawdat al-Afrăh (or Tawärikh al-Hukamä al-Aqdamin), fol. 199 of the Arabic manuscript 4515 at the Fătih Library in Istanbul, Turkey. I wish to express my gratitude to the Fătih Library for allowing me to procure a microfilm copy through the generous assistance of Prof. Dr. S. Unver, and Mr. Ralph G. Talcott of the American Embassy in Istanbul.

17 Kindi, Rasäil al-Kindī al-Falsafiyah, edited by Abū Ridah, Cairo, 1950, vol. 1, pp. 244, 373-6; and 1953, vol. 2, pp. 92-3, 100.

18 Ibid., vol. I, pp. 214-216, and 230; vol. 2, pp. 54-63. Al Kindi also attributed happiness to the purity of the soul (see vol. 1, pp. $277-279$ and 384 ).

10 This guess, based on astrological and Qur'annic interpretations of stars' conjunction and symbolism, came very close to the actual date. Of interest is the author's chronological survey of events which reshaped the political history of the Arabic Empire. See Otto Loth, Al-Kindi als Astrolog, Morgenländische Forschungen. Festschrift $H$. L. Fleisher gewidmet, Leipzig, Brockhaus, 1875, Pt. 7, pp. 263-309. This edition included both the Arabic as well as the Latin text of the epistle.

${ }^{20}$ Philip K. Hitti, History of the Arabs, 6th ed., London, Macmillan, 1958, pp. 158, 444-5.
} 


\section{Sami Hamarneh}

arteriosclerosis, based on clinical interpretation of reported symptoms of the disease. ${ }^{21}$

Al-Kindi's scholarship was well recognized even in his lifetime. While his intellectual activities created many enemies, at the same time they attracted a number of students. Although we are not certain how and when he started to teach and for how long he continued, we know that among his students were several who held prominent positions in the government as well as among the learned. One, for example, was Ahmad ibn al-Tayyib al-Sarakhsi who was studying under al-Kindi between 850 and 851 ; later he became the tutor of Caliph al-Mu'tadid and, in 892, his boon companion. ${ }^{22}$ In 895, al-Sarakhsi was promoted to the important office of the muhtasib of Baghdād to supervise crafts, the market place, and the weights and measures used by the various professions and traders to guard against adulteration and fraudulence. Moreover, he was probably the first to write two manuals on the hisbah office and the function of the muhtasib in controlling frauds in trade. He likewise wrote a few medical works including An Introduction to the Healing Art, in which he refutes a book on the same subject by the famous scholar Hunayn ibn Ishāq (d. ca. 874) ${ }^{23}$ Another famous student of al-Kindi is mentioned by al-Nadim in alFihrist, p. 520. He is Muhammad ibn Yazid known as Dabis, a true alchemist and an artisan who made elegant ceramic wares and wrote a book on leather dyes and inks.

As an author, al-Kindi was prolific. His writings included almost all branches of human knowledge of the medieval period. ${ }^{24}$ Narrators, bibliographers, and historians attributed to him sayings in the form of aphorisms and short poems ${ }^{25}$ which makes it difficult sometimes to distinguish the genuine al-Kindi from the myths surrounding his personality. In addition, numerous treatises and titles of epistles carrying his name, most probably for the sake of prestige,were reported on the basis of mere hearsay. For more positive information, we have to wait for additional and more comprehensive studies of the author's original, extant writings.

Fortunately, however, Ibn al-Nadim (d. 995) listed all the works he knew of in his time that had been written about a century earlier by al-Kindi. There are approximately 239 titles including a minority of book-size works, but the majority short treatises and epistles some of which do not comprise more than

21 Qifți, Ikhbār, pp. 246-7.

22 Al-Sarakhsi (d. 899) was greatly influenced by his teacher, and later likewise fell into disgrace with the palace, was persecuted, imprisoned, and humiliated. See Franz Rosenthal, Ahmad b. At-tayyib As-Sarahsî, New Haven, Conn., American Oriental Society, 1943, pp. 13, 17-18, 24, 81, 125-34.

${ }^{28}$ Nadìm, Fïrist, pp. 379-8I ; and Usaybi'ah, 'Uyün, vol. 2, pp. 191-2.

24 The Encyclopedia of Isläm, pt. 2, Leiden and London, 1927, vol. 2, pp. 1018-19; Hitti, op cit., pp. 370-I.

${ }^{25}$ See Ahmad ibn Miskawayh (d. 1030), Tahdhib al-Akhlä $q$ Wa-Tathir al-A'rāq, Cairo, Taraqqī, 1899, pp. 156-7, and 181-3; Usaybi'ah, 'Uȳ̃n, vol. 2, pp. 182-3; and by Ibn Nubātah, Sarh, pp. 158-6o, among other historians of the period. In Latin, however, the largest collection of sayings and citations attributed to al-Kindi is to be found in Tractatus de erroribus philosophorum, edited by P. Mandonnet, Louvain, 1911. 


\section{Al-Kindī, a Ninth-Century Physician, Philosopher and Scholar}

a few pages. ${ }^{26}$ In regard to contents, several passages are repeated in toto or in part in more than one work. Most of these writings in the original language, especially those relating to the medical sciences, are now lost. There is only one copy of the majority of those extant so that affiliation and collation of manuscripts are not yet feasible. The reasons for the scarcity of these works are obvious: the repeated destruction of intellectual output by reactionary movements, invading enemies and continued wars, the political weakness of the later Abbasid caliphs, and the rapid general decline in creative cultural productivity that followed throughout the whole of the Arab world. In the West, some more of al-Kindi's writings are still extant in Latin versions. Of these, a few have been edited and studied: his epistle on astrology, De signis astronomiae applicatis ad medicinam (based on a Latin manuscript No. 267) in Munich, ${ }^{27}$ and the epistles De intellectu ( $F_{\bar{\imath}}$ al-' $\left.A q l\right)$, De somno et visione ( $F_{\bar{\imath}}$ al-Nawm wäl-Rūyā), De quinque essentiis ( $F \bar{\imath}$ al-Jawähir al-Khamsah), and Liber introductorius in artem logicae demonstrationis ( $F \bar{\imath}$ al-Madkhal al-Mantiq $\bar{\imath}) .{ }^{28}$

Concerning editions in the original language, the credit goes to $\mathrm{H}$. Ritter for discovering in 1932 a series of al-Kindi's epistles in the Arabic manuscript 4832 housed at the Hagia Sophia Library in Istanbul. Together with M. Plessner, he published a useful description of the contents. ${ }^{29}$ Later he and $\mathbf{R}$. Walzer edited one of the epistles, On Expedients For Relief From Sorrows (Fi al-Hīlah Lidaf' al-Ahzän), with an introduction, a general bibliography, annotation, and a translation in Italian. ${ }^{30}$ This remarkable contribution to Arabic literature in psychology and sociology deserves some attention, and is of interest to the history of psychotherapy for here the author elaborated his philosophy of pain. 'Sorrow,' he explained, 'is a spiritual (nafsani) grief caused by loss of loved ones or personal belongings, or by failure in obtaining what one lusts after.' He then added, 'If causes of pain are discernible, then cures can be found.' No one can escape experiencing pain in his lifetime for none of us ever obtained all that he desired or escaped the pain of losing that which he cherished. Duration and perpetuity (dawäm) are non-existent in the corruptible world in which we live. Thus, in a Neo-Platonic manner, he recommended that

\footnotetext{
26 Nadim, Fihrist, pp. 372-9. Later historians mentioned different numbers: Ibn Șä'id reported that they amounted to over 50; Choulant and Leclerc to over 200; while Ușaybi'ah and Sarton bring them up to about 270. For further detail and excellent treatment of the life and works of al-Kindi see Gustav Fluegel, Al-Kindi gennant 'der Philosoph der Araber'. Ein Vorbild seiner Zeit und seines Volkes, published in the Abhandlungen für die Kunde des Morgenlandes, Leipzig, 1857, vol. 1, pt. 2, pp. 2-55, wherein about 265 works are listed.

27 Rudolf Haubold, Ein Münchener Handschriftlicher text angelblich des Alkindz, Diss. 7 p., Leipzig, 1921.

28 Edited with useful annotation by Albino Nagy in 'Die philosophischen Abhandlungen des Ja'qūb ben Isḥāq al-Kindi', Beiträge zur Geschichte der Philosophie des Mittelalters, Munster, Aschendorffschen Buchhandlung, 1897, vol. 2, no. 5. Nagy here explains that in these treatises al-Kindi brought out new ideas not found in Aristotle.

${ }^{29}$ Hellmuth Ritter, and Martin Plessner, 'Scriften Ja'qūb ibn Ishāa al-Kindī's in Stambuler Bibliotheken', Archiv Orientálni, Prague, Czechoslovakia, 1932, 4, 363-72.

${ }^{30} \mathrm{H}$. Ritter, and Richard W. Walzer, 'Studi su al-Kindi. Uno Scritto Morale Inedito di al-Kindi', Reale Accademia Nazionale dei Lincei, 1938, 8, series 6, Fasc. 1, pp. 31-47 Arabic texts and pp. 47-62 Italian translation. In the very useful introduction and commentary pp. $3-30$, the two authors adequately explained the Greek influence on the philosophy of al-Kindi, a fact which deserves the reader's attention.
} 


\section{Sami Hamarneh}

if we do not tolerate losing or dislike being deprived of what is dear to us, then we should seek after riches in the world of the intellect. In it we should treasure our precious and cherished gains where they can never be dispossessed ... for that which is owned by our senses (alqinyah al-hissiyah) could easily be taken away from us.

Then with Aristotelian logic he proceeded, 'Therefore, we ought to want what is, if the desired is not obtainable.' Since losses are expected in life's span, he advised his readers to make them the means 'to adorn (nujammil) themselves with good behaviour and with contentment', urging them to lead a life free of worries about material belongings or the fear of losing them. Thereafter, with rational psychological approach, he explained how our attitude toward most of our griefs as well as joys could be acquired and developed by habit. 'Let us, therefore, train ourselves in the right way so that the pursuit of contentment and the enjoyment of spiritual happiness becomes an ingrained habit ('ädah läzimah) and an acquired trait (khalq mustafäd).' He then reminded his reader, 'Think of past sorrows, how they disappeared. Note also that others have experienced similar losses which are now forgotten. If they, in time, have been comforted why should we not be comforted, also?'

In comparing body and soul, the author affirmed,

If in seeking to be healed from the diseases of the body, we bear the bitterness of medications, the suffering of cauterization and surgery, and are willing to spend large sums of money for medical care, how much more attention should we pay for the care and refinement of our soul (isläh al-nafs) which is far more important ... yet it is more pleasant and rewarding and less costly to treat and restore. ... For we are what we are by the soul and not the body, which is only the tool used by the soul.

He urged, therefore, 'that the soul, through the act of the will, be obliged to develop gradually a good constitution'. These virtues thus 'become a habit, which in turn makes it easier for us to face patiently and quietly trials and hardships and to be comforted in spite of material losses.' $\mathrm{He}$ also warned against repeating acts that caused us grief, and the anxiety resulting from the fear of events before they actually take place. For whosoever grieves himself, injures himself, and he who injures himself is a fool. . . . 'Shorten, therefore, the duration of your grief,' he appealed, 'and do not be content to be miserable when it is in your power to become a happier individual. . . . For sorrow is not in us, we bring it on ourselves ( $\left.a l-u z n w a d^{6} l \bar{a} a b^{6}\right)$. Yes, forget the pains of the past as others did and be happy as they are.' He praised the man who had the will to gain spiritual victory over transient interests.

Politically al-Kindi approached what may be termed extreme socialism in suggesting that

no man should have monopoly of things perceived by the senses, lest he become covetous when they are owned by others who have the same right to them as well. Covetousness, [he added] is an evil. God has the right to give these things to whom He wants. Only the spirit's (mind's) belongings are permanent. None can take them from us.

Philosophically he went even further in saying,

The material things of this world are with us on loan ('ariyah). Therefore, [he continued] we should not regret it when the real Owner takes away what is His. We should not protest that $\mathrm{He}$ took them to give to our enemies. 


\section{Al-Kindi, a ninth-Century Physician, Philosopher and Scholar}

Then with a Platonism mixed with religious conviction he concluded,

All material losses are small. What our spirit owns, which is our most precious possession, remains. No one can rob us of the gifts of the intellect; thus sorrow finds no way to our soul. Let us, therefore, be thankful. . . . Indeed, the one who wishes to be exposed the least to calamities should keep his belongings to a minimum. For the less a man has, the less he will encounter losses and the pains they bring.

Nor did al-Kindi refrain from criticizing human nature when he exclaimed, 'All God's creation, the animals and beasts of the fields and forests and the fish of the sea, all are satisfied and happy with what they have. . . . But man is not.' He attributed to man virtues and powers over God's creation but remarked that 'man uses them to indulge in self-pleasures.' These ambitions multiply his worries and griefs. He becomes entangled with minor holdings and forgets the greatest and most valuable heritage he has.

Finally, and this point al-Kindi argued vehemently with a feeling of spiritual triumph, he said,

Even death is not bad, but the fear of death is. . . . Death is a necessary completion of our being. . . . For if there is no death, there is no man. . . . Comparing other losses with death leads to the conclusion that any material loss is, after all, not bad. . . . To find consolation, therefore, [he concluded] think of permanent possessions which you never lose, then what you had considered calamities are counted as blessings. ${ }^{31}$

From extant works, quotations, and bibliographies, I am inclined to believe that al-Kindi's best contribution was in the realm of philosophy and logic, and after these, the natural sciences including the healing arts. In this respect, he stands as the greatest philosopher of the ninth century who elaborated upon Aristotelian and Neo-Platonic schools of thought, and who ranked for almost a thousand years as one of the most original writers among Muslim philosophers. During his lifetime, a good portion of the authentic works of Aristotle was rendered into Arabic by eminent scholars such as Yahyā ibn Batrīq and Ishāq ibn Hunayn. Al-Kindī himself in his epistle on The Classification (amount, kammiyyat) of Aristotle's Books and What Is Needed (of them) for Learning Philosophy, gave us a list of the most important ones. ${ }^{32}$ The epistle was edited together with twenty-eight others, with very useful introductions and annotations, by Professor Abū Ridah in one of the most comprehensive and scholarly studies of the original philosophical works of al-Kindi published thus far. ${ }^{33}$ Here in a classified list, al-Kindi divided into four categories the works of Aristotle which he thought each student of philosophy should study. They are: Categoriae; De interpretatione; Analytica priora, On syllogism; Analytica posteriora, On demonstra-

31 My translation of the quotations is based mainly on edited Arabic text in the above-mentioned article.

32 This epistle was edited with annotation and translation in German by August Mueller, under the title, 'Das arabische Verzeichniss der aristotelischen Scriften', Morgenländische Forschungen, Leipzig, Brockhaus, 1875, pt. I, pp. I-18. It is of interest to note how this list reveals that the major part of the Aristotelian corpus was available in Arabic long before the end of the gth century. Pseudo-Aristotelian works were also translated into Arabic. One, on the theology of Aristotle, translated by 'Abd al-Masih Nā'imi of Homs, Syria, reportedly was corrected by al-Kindi. See Friedrich Dieterici, Die sogenannte Theologie des Aristoteles aus arabischen Handschriften. Die Philosophie der Araber, Leipzig, 1882-3, vols. 12-13.

${ }^{33}$ Muhammad 'Abd al-Hādĩ Abū Ridah, Rasă il al-Kind̄̃ al-Falsafiyah, 2 vols., Cairo, Dār al-Fìrr al-'Arabì, 1950-3. Hereafter, in citing al-Kindi's original writings, unless otherwise stated, I will be referring to this noteworthy edition. 


\section{Sami Hamarneh}

tion; Topica, On dialectical syllogism; Sophisticis elenchis; Ars rhetorica; De poetica; Physica auscultatio; De coelo; De generatione et corruptione; Meteorologica; De partibus animalium; De anima; De sensu et sensili; De somno et vigilia; De longitudine et brevitate vitae; Metaphysica; Ethica Nichomachea, in eleven sections; Magna moralia; and Ethica Eudemia, written, according to al-Kindi, to Eudimus and containing seven treatises. Besides these authentic works, al-Kindi mentioned two spurious books: On Plants and On Minerals, attributing them to Aristotle. This list, nevertheless, shows al-Kindi's acquaintance with the major works of Aristotle, 'the foremost (greatest, mubarriz) among the Greek philosophers . . . and, with his teacher Plato, the most praiseworthy of all the ancient philosophers. ${ }^{34}$ Because of his admiration for philosophy and the natural sciences, al-Kindi devoted a major part of his active life to the dissemination of classical learning in Islamic culture. ${ }^{35} \mathrm{He}$ was widely read for several centuries. In the twelfth century, a number of his writings were translated into Latin by Johannes Hispalensis, Gerard of Cremona, and others, and were perhaps more favourably received in the West than in his native land..$^{36}$ His eclecticism borrowed from later Hellenistic interpreters, his objectivity, and his sincere devotion to personal observation and logic, made him a target of bitter attacks from rulers, men of letters, theologians, and historians. The judge of Toledo Ibn Sā'id (d. 1070) criticized his philosophical method as lacking in analytical interpretation and condemned his ideas and conclusions as useless. 'He was led astray from the right course,' Ibn Șā'id charged, 'after embracing erroneous doctrines.' Al-Qiftī (I 172-1248), repeated the same criticism. ${ }^{37}$ Ibn Abi Usaybi'ah (1203-i270), however, refuted 'these charges against him as an open assault which should not infringe upon the integrity of al-Kindi's intellectual importance or deprive people of the benefit of reading his books. ${ }^{38}$

In pursuing Aristotelian and Neo-Platonic reasoning, al-Kindi, throughout much of his active life, endeavoured to harmonize the views of Plato, especially in later modified forms, with those of Aristotle, in defiance of orthodox dogmas. 'We ought not to be ashamed to applaud and accept the truth,' he affirmed, 'from whatever source, even if it comes from far-off places or foreign nations who have different cultures from ours. For nothing is more important to the seeker of the truth than truth itself.' 39 Furthermore, he attempted to reconcile philosophy with religion, especially regarding the omnipotence of the Creator and monotheism, a topic on which he wrote more than one treatise. He faithfully attempted to express his convictions and beliefs in upholding

34 Kindī, Abū Ridāh edition, vol. 1, pp. 103 and 353.

35 George Sarton, Introduction to the History of Science, Baltimore, Md., Williams \& Wilkins, 1927, vol. 1, p. 559; Th. G. de Boer, 'Zu Kindi und seiner Schule', Archiv Geschichte der Philosophie, 1899, 13, 177-82; and Jirji Zaydān, Tărikh Ădāb al-Lughah al-'Arabiyyah, Cairo, Hilāl Press, 1912, vol. 2, pp. 212-83. See also, M. K. al-Țuraihị, al-Kindī Faylasūf al-Arab al-Awwal, Baghdād, As ad, 1962, pp. 85124, including his edition of Fi Daf" al-Ahzän based on the Tehran and Istanbul manuscripts.

${ }_{36}$ Leclerc, Histoire, 1876, vol. 1, pp. 166-7; Donald Campbell, Arabian Medicine and Its Infuence on the Middle Ages, London, 1926, vol. I, pp. 64-5; and Ludwig Choulant, Handbuch der Bücherkunde für die Altere Medicin, Leipzig, L. Voss, $184 \mathrm{I}$, pp. 336-7.

37 Ibn Șāid, Tabaqät, pp. 59-60; and Qifți, Ikhbār, p. 240.

38 Usaybi'ah, 'Uyun, vol. 2 , p. 180.

so Kindi, Fí al-Falsafah al-Ulä, Abū Ridah's edition, vol. I, p. 103. 


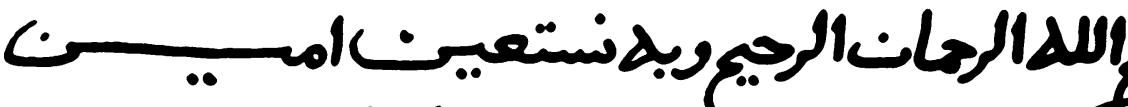

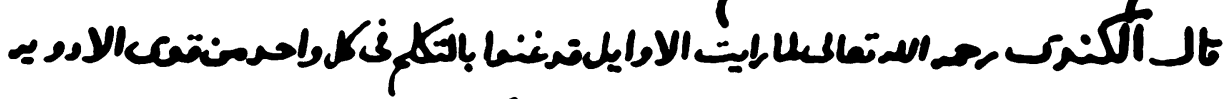

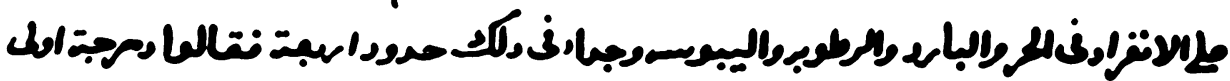

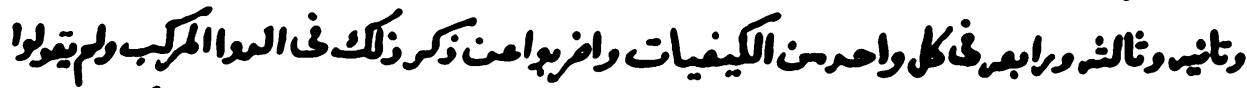

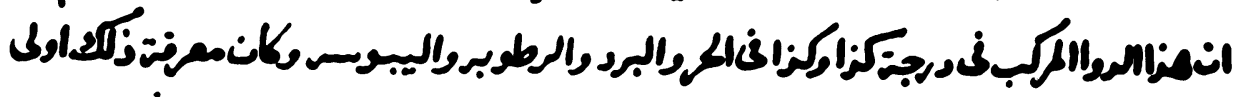

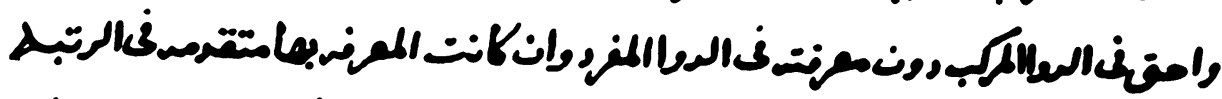

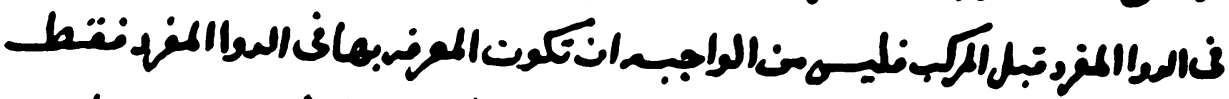

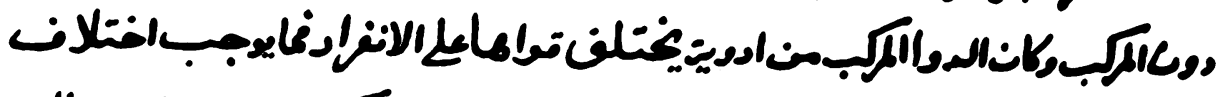

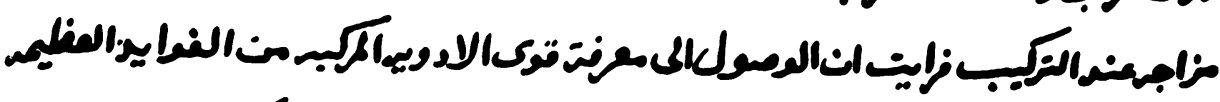

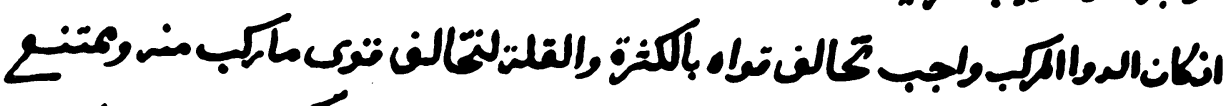

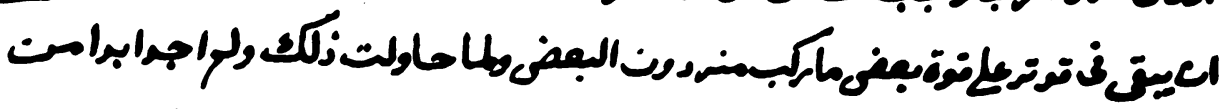

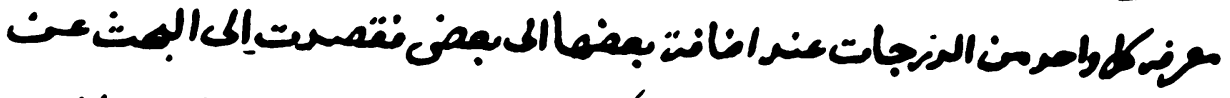

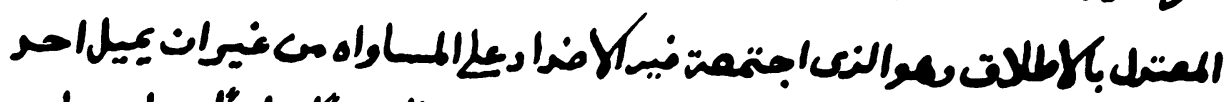

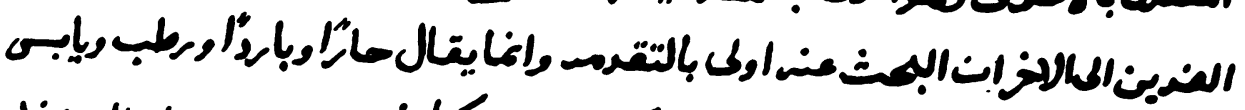

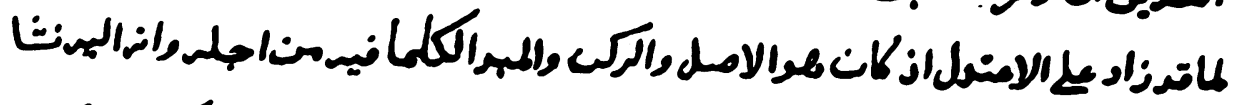

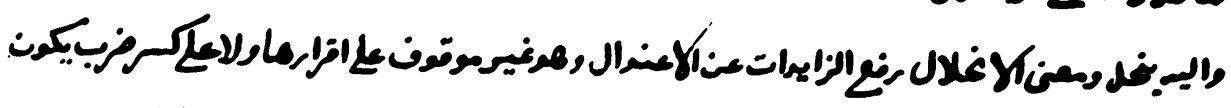

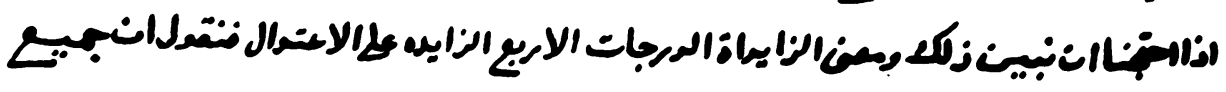

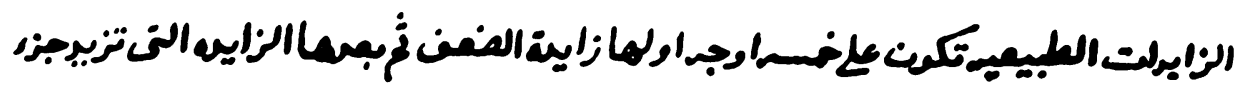

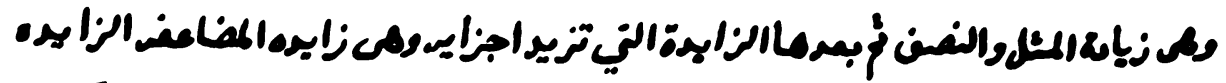

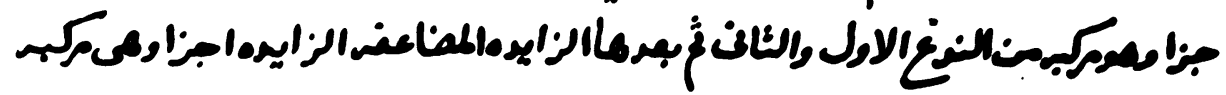

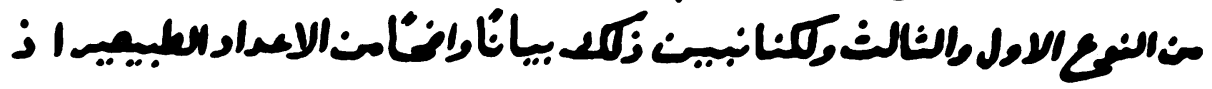

Fig. I

The introductory page to al-Kindis treatise on the knowledge of the faculties of compounded drugs. (By courtesy of the Bayerische Staatsbibliothek, Germany.) 


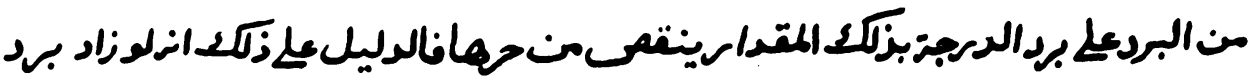

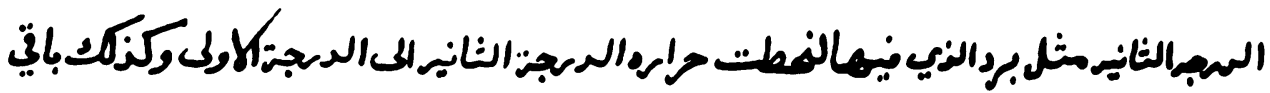

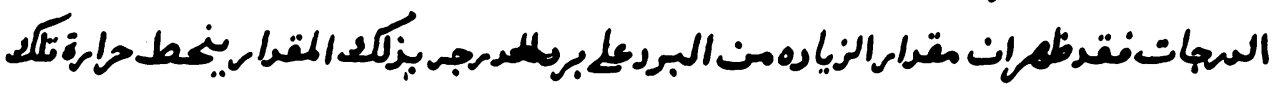

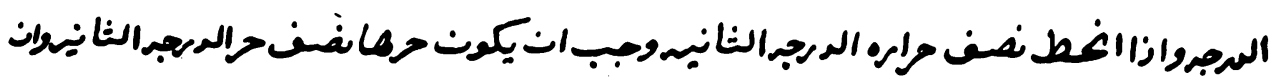

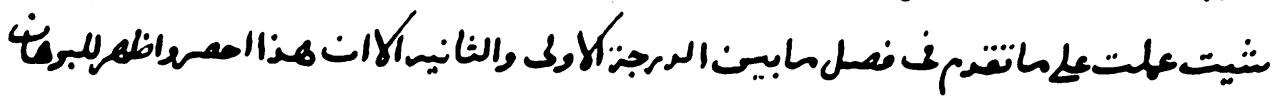

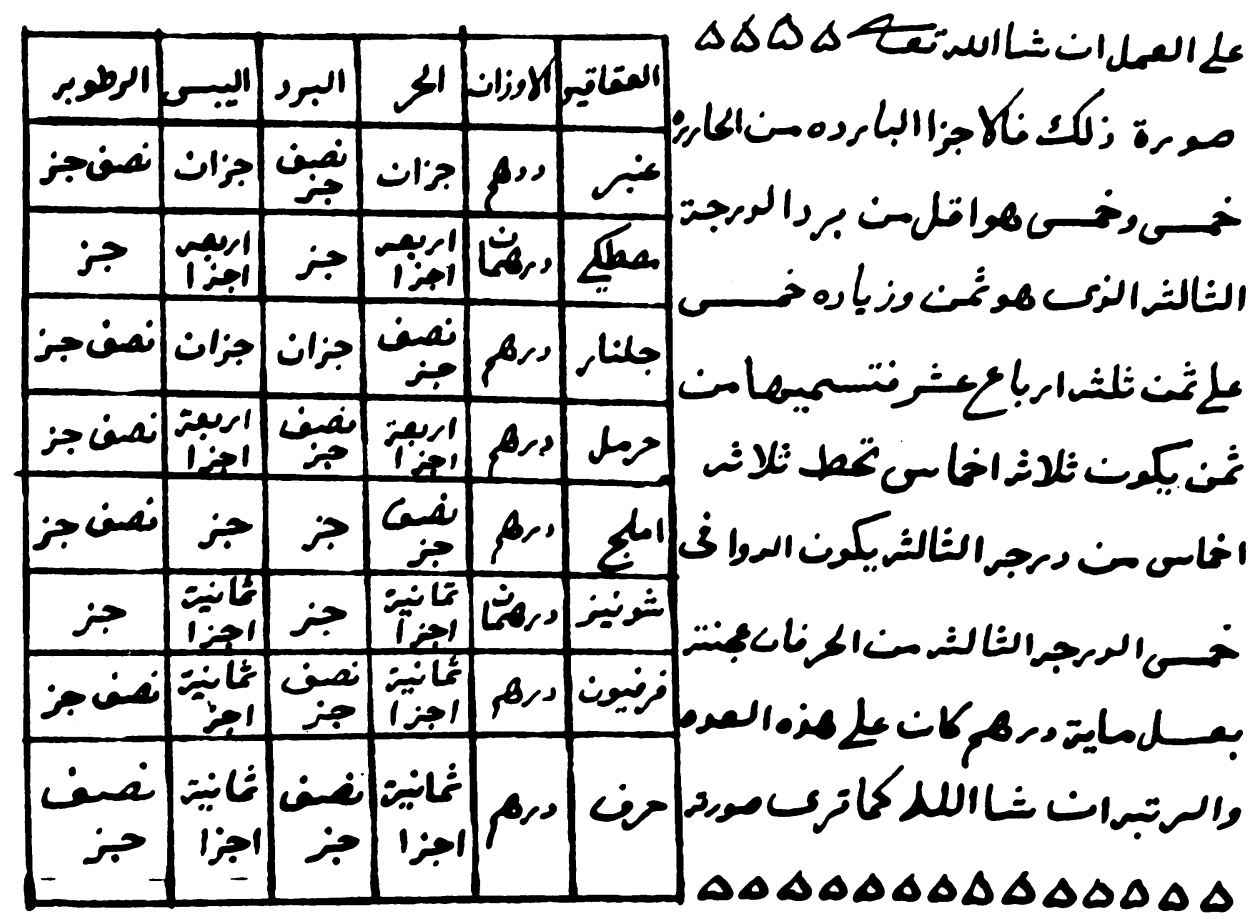

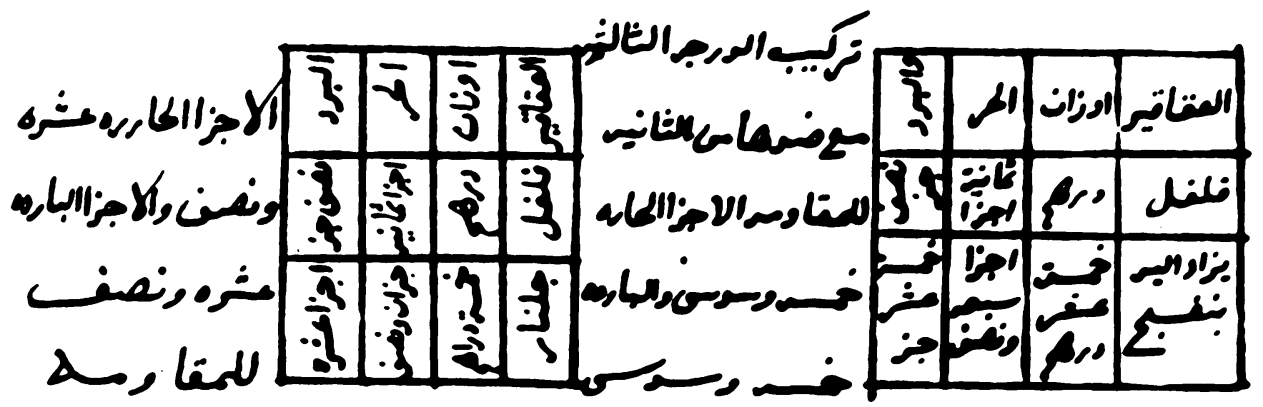

Fig. 2

Tables and text showing al-Kindi's approach and method of calculating the properties of compounded drugs. (By courtesy of the Bayerische Staats-

bibliothek, manuscript Cod. arab. 838.) 


\section{Al-Kindi, a Ninth-Century Physician, Philosopher and Scholar}

the Qur'ān and his adherence to the Muslim faith. He also argued that philosophy could not be attained without a thorough acquaintance with arithmetic ('ilm al-'adad), geometry, astronomy, and general mathematics (al-tälïf).40 Then in a Neo-Pythagorean fashion he goes on to consider mathematics as the basis of all branches of science. This is evident in his writings not only on philosophy, physical sciences, astronomy, geometry, and arithmetic, but also on music and natural sciences. He applied it to medicine as well in his treatise on the posology of compounded medications $F \bar{\imath} M a^{6}$ rifat $Q u w \bar{a}$ al-Adwiyah alMurakkabah of which an Arabic manuscript exists in the British Museum.

A further copy exists in the Bayerische Staatsbibliothek and I am grateful for their kind cooperation in sending me a microfilm of the manuscript number Cod. arab. 838 , fols. $28 \mathrm{r}$ to $37 \mathrm{r}$. This copy was written by Mikhä'îl son of Shukrällah al-Mārūni of Aleppo, Syria, and completed on Saturday, the 27th of October, I 759 and seems to be well executed (see Figs. I and 2). Earlier, this work had been translated into Latin by Gerard of Cremona (d. I 187 ) under the title De Medicinarum compositarum gradibus investigandis Libellus. Here, the author attempted to distinguish between intensity and qualities of drug preparations. 'Greek physicians,' he asserted, 'discussed and explained the faculties and qualities of simple drugs only. But they failed to do so in regard to compounded medications, which are even more significant.' The author thus applied the law of geometrical progression to the Galenic doctrine of qualities and degrees of the simple drugs in a particular composite medicine. Then he calculated the total degrees and qualities of the individual ingredients to count the determining faculties of the given compound. ${ }^{41}$ In the late tenth century, Abū al-Qāsim Khalaf al-Zahrāwĩ (Latin Abulcasis) and other physicians in Islam attempted to utilize this method in their medical practice. In view of this new approach, al-Kindi was considered a precursor of the nineteenth century founders of modern psychophysics, E. H. Weber and Th. G. Fechner. ${ }^{42}$ At the same time, as a mathematician, he corrected treatises 14 and 15 of Euclid's Elements, as his bibliography shows.

In his psychology, as I noted earlier, al-Kindi drew more upon Aristotle than on later commentators. This seems evident from his work On Sleep and Visions (dreams). Furthermore, he stated in his epistle On the Soul that it is a synopsis of a book of Aristotle and the writings of Plato and other philosophers. ${ }^{43}$ His epistle on the intellect, $F \bar{\imath}$ al-' $A q l$, although basically Aristotelian in tone and substance, shows independence and originality. Apparently written at the instigation of a friend, this letter summarized in definite terms al-Kindi's views and interpretation of Aristotle's concept 'which sums up Plato's general ideas' on the intellect. Al-Kindi divided the intellect into four parts, one primary and three secondary.

40 Ibid., pp. 364 and 369 .

41 For greater detail see Curt Lantzsch, Abu Jusuf Ja'kub Alkindī und seine Schrift 'de Medicinarum Compositarum gradibus'. Ein Beitrag zu dem Kapital Mathematik und der Medizin in der Vegangenheit, Leipzig, 1920, a study based on a Latin version of al-Kindi's work.

42 This is well-explained in Leon Gauthier, Antecédent Gréco-Arabe de la psychophysique, Beirut, 1939.

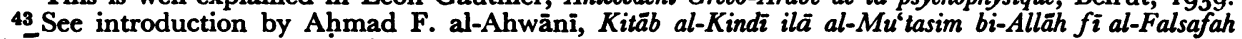
al-Ūlă, Cairo, Ihya, 1948, p. 46; and al-Kindī, Abū Ridah's edition, vol. 1, pp. 272-3 and 293-318. 


\section{Sami Hamarneh}

The first is the intellect in actuality. The second is the faculty of intellect within the soul. ... . The third is that intellect which develops from the potential into the actual within the soul. It becomes the soul's own possession to be revealed and utilized whenever the need arises . . . in the same way as the ability of a scribe to write. It therefore resembles a talent owned and planted in the soul ready for use at any moment. . . . The fourth is the apparent (visible, $z \bar{a}$ hir) intellect made manifest only when the soul brings it into actuality. Thus it differs from the third in that it becomes the soul's possession only when in use, whereupon it develops into actuality, whereas the third is in the soul's possession at all times.44

In this organization and method of approach, al-Kindi is clearly adding a new idea to the Aristotelian concept.

Not many of al-Kindi's writings on physical sciences are extant. But it seems plausible to assume from extant works and information that he was an ardent experimentalist. For example, to illustrate the fact that substances when heated expanded, he demonstrated the phenomenon through experimentation.

'This could be easily explained by observing an experiment to illustrate it. . . . Take a bottle or any glassware in the shape of pitchers used in public baths and invert it so that the opening of the bottle touches the surface of water underneath, heat it and watch. As the heated air expands (izdād al-hawā), the water ascends to take the place of air escaping from the bottle. The air, expanding beyond what it was at first, needs more space. It pushes through the water (zakham al-ma) in the vessel and goes out, forming small bubbles with a fizz depending on the amount of heat. If thereafter the air is cooled more than it was before heating, it contracts and occupies a smaller space. Its size decreases in the vessel, and thus the water is attracted to fill in the space filled earlier with that portion of the hot air which escaped through the water. Thus we observe by sight the water coming up the neck of the bottle above the surface of the water. This clearly explains that when substances are heated they get bigger, and they get smaller when cooled.'45

Another more interesting experiment is the one in which he illustrated with much enthusiasm 'how motion forms heat', by showing that metal dissolves if projected rapidly through the air and for a long distance. He corrected Aristotle, arguing

we tried it because carrying out an experiment was quite possible, and we believe that when a statement is based on an experiment that can be sensed, then it cannot be discredited except by proof that it does not happen. Therefore, [al-Kindi continued] we made our own projectile to carry on the experiment. ${ }^{46}$

According to historical records, al-Kindi even wrote a few treatises on making scientific instruments including a clock, a telemeter, an astrolabe, and an abacus (mukhrijat al-jawämi $\left.{ }^{6}\right){ }^{47} \mathrm{He}$ could have been only a theorist. After I submitted this article, Mr. Silvio A. Bedini generously showed me a microfilm of the Ms. Marsh. 663 (7a) pp. 1901-95 of the 'Amal al-Să'ah of al-Kindi housed in the Bodleian Library. The introductory statements are typical of the author's style and confirm its authenticity. It is a treatise on the making of clocks on

44 Ibid., pp. 353-8. This epistle On the Intellect was translated twice into Latin during the twelfth century. The better of the two translations was made by Gerard of Cremona under the title Verbum Jacob Alkindi de intentione antiquorum in ratione. See Aḥmad F. al-Ahwānī, Talkhīs Kitāb al-Nafs . . ., pt. 4, Risälat al-Kindī fi al-'Aql, Cairo, Imp. Misr, 1950, pp. 1 78-81; Et. Gilson 'Les sources greco-arabes de l'Augustinisme Avicennisant', Archives d'histoire doctrinale et littéraire du Moyen Age, 1929, Paris, 4, 5-27; and Manuel Alonso, 'Traducciones del Arcediano Dominigo Gundisalvo', Al-Andalus, 1947, 12, Fasc. 2, 308-15.

45 Kindi, On Tides (Fï al-'Illah al-Fäillah fï al-Madd wäl-Jazr), Abu Ridah's edition, vol. 2, pp. 11 5-16.

46 Ibid., pp. $117-18$.

17 Nadim, Fihrist, pp. 372, 375, and 378-9. 


\section{Al-Kindī, a Ninth-Century Physician, Philosopher and Scholar}

a plate erected on a plane parallel to drawn horizontal lines. Spaces have been left for the drawings, but unfortunately they are empty. The treatise gives no proofs, only the instructions.

Al-Kindi also made observations from the two shores of the Tigris to demonstrate the speed of sound. He mentioned how 'lightning and thunder take place at one time. . . . Thunder is caused by a split (rend, inkhiräq) in the clouds. ... Light is seen before hearing the thunder, for light is sensed by sight in no time (bilä zamān). ${ }^{\mathbf{4} 8}$ Depending on sight alone, al-Kindi was not able to detect duration in the passage of light. It is worth noting that he made the comparison between sound and light in experimental observation as well as in natural phenomena such as lightning and thunder. In these instances, therefore, he gave experimental evidence as well as a priori reasoning.

Other topics related to physical sciences were not neglected by al-Kindī: colour and the so-called Aristotelian elements, geology, and meteorology, including causes of eclipse, winds, fog, and rain. He described the rapid evaporation of waters by the heat of the sun and the currents in sea and sky from changing temperature which causes rain or snow. ${ }^{49}$ More interesting, however, is his elaborate discussion of the tides. ${ }^{50}$ Although much of it is based on philosophical speculations and the role of heavenly bodies (al-ashkhäs al 'aliyah), sun, and winds, in certain respects the author came close to modern concepts. He described the tides' surge in relation to changes of 'atmospheric temperature', the direction of air and winds and the organized movements of earth and planets in their orbits. 'Flow and ebb is, therefore, deemed necessary,' al-Kindi observed, 'so that things (in the universe) keep connatural (invariable, thawäbit) in their established course, with one system and one arrangement (tadbir).' Then in speaking of what he termed 'the daily flow and ebb,' he emphatically declared that 'the major factor in its taking place is the moon'. $\mathrm{He}$ also made interesting remarks regarding the high and neap tides. ${ }^{51}$ Here he gave a relatively good estimate of the size of the Mediterranean Sea in width as well as in length from Tyre and Sidon to Gibraltar. In another epistle, the author denied that the azure-blue we see in the sky above is its real colour. The air is transparent (mushiff), he argued, and the colour we actually see is the reflection of light from vapours and particles of dense bodies (constraint, munhasirah) carried up into the atmosphere. ${ }^{52}$ The above-mentioned treatises

${ }^{48}$ Kindi, On the Causes of Snow, Hail, Lightning and Thunder, and Cold Wind (zamharir), Abū Ridah's edition, vol. 2, pp. 80-5.

49 Ibid., vol. 2, pp. 70-3, 80-2, and 111 .

50 For further information on al-Kindi's epistle on flow and ebb (Fi al-Madd wäl-Jazr) with a German translation, see the important study by Eilhard Wiedemann, 'Al-Kindi's Schrift uber Ebbe und Flut', Annalen der Physik, 67, 1922, pp. 374-87.

51 Kindi, Fì al-Madd wäl-Jazr, Abū Ridah's edition, vol. 2, pp. 122, 124, and 128.

52 Kindī, Fĩ Illat al-Lawn al-Làzawardì . . ., Ibid. pp. 103-8. In this treatise, al-Kindi gave an original interpretation, independent from that of Aristotle, which surpassed that given by the Muslim natural scientist Ibn al-Haytham (Latin Alhazen, d. 1039). See O. Spies, 'Al-Kindi's treatise on the cause of the blue colour of the sky', J. Bombay Branch of the Royal Asiatic Society, 1937, 13, 7-19. The epistle on the tides was praised by al-Mas udi, in al-Tanbih, Pp. 11,51 . A fine manuscript of this work is reported at Bodleian Library in Oxford. 


\section{Sami Hamarneh}

include, furthermore, several passages of interest to the history of geography, climatology, and geophysics.

In regard to medicine and allied sciences, al-Kindi contributed, according to the list in Ibn al-Nadim's al-Fihrist (complete 987/8), twenty-two works, most of which are in the form of short treatises or epistles. ${ }^{53}$ The following is my translation of the titles:

On Hippocratic Medicine, On Virulent (deadly, muhlik) Drugs, On Vapours which Ameliorate the Atmosphere from Plagues, On Drugs which Heal from Harmful Odours, On Illness which Causes Blood Spitting, On Antidotes, On Preservation of Health, On Delirium of Acute Diseases, On the Soul of the Body's Major Organ (probably the brain, which al-Kindi considered 'the noblest organ in the human body that controls the senses, motion, and other noble functions'), ${ }^{54}$ and Elucidation of Its Essential Parts, On the Brain (whether this treatise is the same or a continuation of the previous letter is not yet known, but it appears safe to state that alKindi had departed here from the Aristotelian concept on the function of the brain), On Leprosy and Its Treatment, On Mad-Dog Bite, On Symptoms Resulting from (excess of) Phlegm and the Cause of Sudden Death, On Stomach Ache and Gout, $A$ Letter to a Man Who Complained (to al-Kindi) Concerning a Certain Ailment (I do not know the subject of this complaint, and it would be of interest if one or more Arabic manuscripts of this letter could be found), On Kinds of Fevers, On Medical Treatment Against a Morbid Hardening of the Spleen, On Decomposed Animal Bodies, On Recognising the Great Value of the Healing Art (in refutation of contemporary critics of the profession such as al-Jāhiz), On Foods Made of Substitute Ingredients (imitations of genuine foods such as chickens, eggs, meat sauce, etc. This treatise was bitterly attacked in later hisbah manuals on trade controls for fear of paving the way for more frauds in food markets), and $O n$ Adulteration of Foods.55

The same source lists the following works by al-Kindi which are related to the chemical and pharmaceutical industry:

On Kinds of Precious Stones, On Kinds of Stones (minerals), On Glass-Blowing and Welding, On Dye Colouring, On Swords and Iron and Methods To Make Swords which Resist Becoming Blunt or Dull (possibly made of steel), ${ }^{56}$ On Making a Longnecked Brass Boiler which Whistles as Vapour Escapes (al-qumqum al-nabbäh), On

\footnotetext{
53 Compare this list with titles mentioned in Qifti, Ikhbär, p. 244; Michael Casiri, Bibliotheca ArabicoHispana Escurialensis, Madrid, I 760, vol. I, pp. 357-60; and Fluegel, $A l$-Kindi, pp. 1 7-19.

54 Shahrazūir, Nuzhat, fol. 200. This treatise of al-Kindi, which deserves further study, seems to revolve around an explanation of the brain's soul and its relation to sensation; whereas Aristotle insisted that the brain had nothing to do with sensation. See Edwin Clarke and Jerry Stannard, 'Aristotle on the Anatomy of the Brain', J. Hist. Med., 1963, 18, 130.

55 Nadim, Fihrist, pp. 375-6.

56 Faysal Dabdüb in his article 'Risālat al-Kindī fì 'Amal al-Suyūf', $A l$-'Ulüm, Beirut, 1963,8 , no. 3, pp. 78-80, comments briefly on this epistle On the Making of Swords. He states that al-Kindi presented methods and techniques whereby carbon and manganese are incorporated in relatively high proportions with iron for the manufacture of excellent steel swords. Al-Kindi's sources varied from Greco-Roman, Syrian, Persian, and Indian tradition to what he learned from people in the land of his ancestors, Yaman (Yemen), and from craftsmen in Iraq such as Hasan al-Kharrăt and a certain Khadr al-Shaykh (the master). Later Muslim authors including al-Birūni (973-1048), and the sixteenth century learned artisan Muhammad ibn Abi al-Khayr al-Hasani, were influenced by this epistle of al-Kindi to al-Mu'tașim.
} 


\section{Al-Kindi, a Ninth-Century Physician, Philosopher and Scholar}

Kinds of Perfumes, and On the Chemistry of Perfumes ${ }^{57}$ (a treatise concerned with the preparation of aromatic medicaments and cosmetics). ${ }^{58}$

During al-Kindi's time, the art and technique of alchemy reached its first climax in Islam and had, apparently, many adherents and supporters among the educated and well-to-do. This flourishing of alchemical activities came, therefore, much earlier than the date of the rise of the Faithful Brethren (Ikhwän al-Safä) and the writing of their epistles in the tenth century. Al-Kindi was, nevertheless, a staunch opponent of alchemists and repudiated their speculations in two treatises, On Warning Against the Fraudulence of Alchemists, and On the Fallacy of Those Who Claim (ability) to Make Gold and Silver and Their Impostures. ${ }^{59} \mathrm{He}$ believed that precious metals found in and made by nature could not be reproduced by the skill of man. Furthermore, he criticized the use of symbolism and mysticism in the sciences, although he repeatedly mentioned 'intelligences of incorporal substances', and predicted good and bad luck in relation to the heavenly bodies (al-ashkhäs al-samäwiyah or al-'aliyah) and their influence on the universe and the destiny of man, a fact that exposes his astrological approach. He himself used secret letters and symbols in his treatise on the making of swords.

Zoological treatises on birds, bees, etc., are also attributed to him. The biographer al-Bayhaqi (d. I I 7o) admired al-Kindi as a scholar 'and a very learned engineer'. He found his work on optics also extremely useful in clarifying this science.60 Indeed, in its Latin version De aspectibus, this treatise exerted much influence on prominent men of learning in the medieval West, including the English philosopher and scientist Roger Bacon (d. I292) and the Polish Witelo. ${ }^{61} \mathrm{Al}-\mathrm{Kindi}$ likewise made an impact on the development of musical theory in the Middle Ages. He introduced a definite pitch notation in his epistle On Harmony of Sounds ( $F \bar{\imath}$ al-Iqā), and other original treatises on music, the first known in Islam. ${ }^{62}$ It is of interest to note here that he utilized music in the treatment of his patients (psychotherapy). ${ }^{63}$

In studying most of al-Kindi's extant works, I found that his style is vigorous

57 Nadim, Fihrist, pp. 378-9.

${ }^{58}$ See Kimiyā al-'Itr wăl-Tas'idat, edited and translated with useful annotation by Karl Garbers under the German title Buch uber die Chemie des Parfums und die Destillationen, ein Beitrag zur Geschichte des arabischen Parfumchemie und Drogenkunde aus dem 9. Jahrhundert, Leipzig, 1948.

${ }^{59}$ Nadīm, Fihrist, pp. 378-9. The physician al-Räzì (d. 932) opposed al-Kindĩ and criticized him for attacking the art of the alchemists.

${ }_{60}$ Zahir al-Din 'Alī ibn Zayd al-Bayhaqi, Tatimmat Șiwän al-Hikmah, Lahor, India, 1351 A. H. [1932], p. 25 .

61 Wiedemann, 'Aus al-Kindī's optik', Beiträge zur Geschichte der Naturwissenschaften, 1907, 13, 245-8; and A. A. Björnbo and Seb. Vogl, 'Liber Jacob Alkindi de causis diversitatum aspectus et dandis demonstrationibus geometricis super eas; De aspectibus', Drei optische Werke, Leipzig, 1912, containing a translation and commentary on al-Kindi's optics based on the Latin translation by Gerard of Cremona.

${ }^{62}$ Henry G. Farmer, 'Clues for the Arabian influence on European musical theory', J. roy. Asiatic Soc., 1925, 61-80; George Sarton, Introduction to the History of Science, Baltimore, Md., Williams and Wilkins, 1927, vol. I, pp. 559-60; and Nadim, Fihrist, p. 373.

${ }^{63} \mathrm{Q}$ ifti, Ikhbar, pp. 246-7. For a better understanding of the development of music by al-Kindi and other Arabian musicians, the reader may wish to consult the works of Henry George Farmer on the subject. See for example his Historical Facts for the Arabian Musical Influence, in Studies in the Music of the Middle Ages, London, Reeves, 1930 , pp. 3-37, $177-180$, and 247-329. In it he describes al-Kindi's one scheme motation, the Tarkib and Tad'if, rhythm, and mensural values (see pp. 25-27, 58-60, and 312-315). 


\section{Sami Hamarneh}

and moving. He writes with conviction and with the dignity of a scholar. Although occasionally he repeats a statement or a passage to make it clearer to the reader, he is always objective and to the point, hence the majority of his treatises are short. He exhibited the modesty of a true investigator in confessing that not all natural phenomena are understood or explained. 'Thus if their beginnings, causes, and effects are yet unknown,' he remarked, 'then it is almost impossible to comprehend all related facts.' 64 In subject matter, alKindi's writings show resourcefulness and catholicity. Most of his extant works are addressed to patrons or friends who requested that he write on particular themes. This seems to be a general attitude of the majority of authors in medieval Islam. Since Arabic was not thoroughly developed during the first half of the ninth century in the fields of philosophy, psychology, and the natural sciences, al-Kindi became one of the great pioneers in developing suitable terminology. And in numerous cases his choice of words was excellent, notwithstanding that in several passages the meaning is distorted or lacks clarity because of the difficulty in finding the right expressions. His contribution to Arabic philosophy is considerable. Many of the terms he used or adapted are still in use today. If we are to consider the epistle $F \bar{\imath}$ Hudiud al-Ashya $w a-R u s \bar{u}-$ miha (on the definition and identification of terms) to be authentic, then alKindi should be considered the first in Islam to write a 'scientific' lexicon. Although one of the most independent thinkers of the medieval period, he defended revelation and demonstrated a thorough knowledge of the spirit of Islam. Ibn Juljul (d. ca. 997) said of him, 'He explained, summarized and simplified the salient and difficult points in philosophical texts (of the Greeks) and wrote a book on monotheism that surpassed all of its kind. ${ }^{65}$ When more of his works are brought to light, a better evaluation of this ninth-century scholar will become more feasible. Present findings, nevertheless, justify the remark that he was truly the 'philosopher par excellence', who demands our admiration, and that his influence and contribution to Arabic philosophy and sciences in the Middle Ages were not exaggerated. ${ }^{66} \mathrm{He}$ paved the way for later Muslim philosophers, physicians, and scholars such as al-Färābī (d. 950) and Ibn Sinā (Avicenna, d. I037) in the Eastern Caliphate, and Ibn Rushd (Averroes, d. I 198) in Muslim Spain.

64 Kindī, Fì al-'Illah al-latī lahā Yabrud A' 'lă al-Jaww . . ., Abū Ridah's edition, vol. 2, p. 9 I.

65 Ibn Juljul, Tabaqat, pp. 73-4.

of Leclerc, Histoire, vol. I, p. $16 \mathrm{I}$. I am indebted to the Ministry of Education and Guidance of the Republic of Iraq for sending me a free copy of the invaluable work on al-Kindi's writings by Father Richard J. McCarthy of the University of Wisdom in Baghdad. It lists all works written by al-Kindi or attributed to him, the manuscripts available, their location, and numbers, under the Arabic title, al-Tasünif al-Mansübah ilä Faylasüf al-'Arab, Baghdad, al-'Ani press, 1962. The same press issued

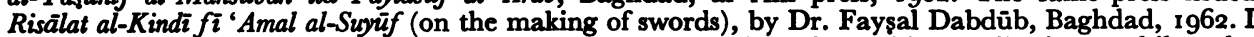
also received Kürkis 'Awwad's Al-Kindī ... His Life and Works, 1962, on his contribution to philosophy by 'Abd al-Karim al-Zinjäni, in a booklet entitled al-Kindī Khälid bi-Falsafatih, al-Najaf, 1962. 